\title{
Why Is the U.S. Share of World Merchandise Exports Shrinking?
}

\author{
Benjamin R. Mandel
}

\begin{abstract}
As the U.S. share of the world goods trade slips from its level in the 1980s and 1990s, concerns have arisen that the productivity of U.S. exporters has not been growing as fast as that of foreign firms selling similar products. However, an analysis of industrylevel trade data suggests that two other factors explain much of the drop in export share: the changing composition of the products traded internationally and the diminished share of U.S. GDP in global output. Declining relative productivity may have played a role in the early 2000s, but it has not been a large factor across industries over the longer term. Overall, there is little evidence of a broad-based decline in the nation's ability to compete in global markets.
\end{abstract}

\footnotetext{
- he U.S. market share of world merchandise exports has declined sharply over the past decade. Throughout the 1980s and 1990s, approximately 12 percent of the value of goods shipped globally originated in the United States; by 2010, the share had dropped to only 8.5 percent. Some observers have sought to explain the nation's diminished role in merchandise trade by suggesting that U.S. industry has shifted its energies from the export of goods to the export of services. As we shall see, however, the trade data offer no support for such an argument; in fact, they show that the U.S. share of world services exports also plummeted over the last decade.
}

How, then, can we account for the United States' flagging merchandise export performance? Have U.S. manufacturing firms simply become less competitive than their foreign counterparts? Underlying this concern is the fear that, over time, the productivity of U.S. firms has fallen relative to that of foreign firms selling similar products (Box 1). ${ }^{1}$ Declining relative productivity would mean that U.S. firms were less able to price competitively against other exporters - a disadvantage that would lead to a loss of revenue share in common export markets.

This edition of Current Issues investigates the factors driving the fall in the U.S. export share and, to the extent possible, attempts to determine how big a role the changing productivity of U.S. firms relative to their competitors has played. The most direct way to address this question would be to compute relative productivity measures for all U.S. export industries. However, in many instances, and particularly for international comparisons, the existing data are not detailed enough to gauge this directly. Thus, we take a different approach, considering other factors that might have lowered the U.S. export share and assessing the extent to which they can explain the observed decline. The portion of the export contraction that remains unexplained after

\footnotetext{
${ }^{1}$ In a prominent example of this view, Jeffrey Immelt, chief executive officer of General Electric and chair of the President's Council on Jobs and Competitiveness, said: "We need a coordinated commitment among business, labor, and government to expand our manufacturing base and increase exports.... For example, we have returned many GE appliance manufacturing jobs to the [United] States by collaborating with our unions and making our operations more efficient"' (Washington Post, January 21, 2011).
} 
we take these factors into account provides some measure of the effect of declining relative productivity, or of reduced competitiveness more generally.

We find that two alternative factors can account for much of the decline in the U.S. export share. The first relates to the composition of world trade. If the rest of the world is increasingly trading goods that the United States does not produce, then the U.S. export share will fall—even if U.S. firms remain just as productive as their competitors in the goods that they do export. When we investigate this possibility by decomposing changes in the U.S. market share into contributions from individual product groups, we find that only a handful of products contributed to the share decline. Among those that did contribute, a significant part of the decline was indeed driven by the shrinking fraction of world trade claimed by those products. While we also find that the United States lost ground to its competitors in the export of certain products that were expanding briskly as a share of world trade - in particular, machinery and transportation productsthe change in the overall U.S. export share cannot be interpreted as a simple proxy for the nation's reduced competitiveness.

The second factor that helps explain the declining U.S. export share is the relatively slower growth rate of the U.S. economy relative to that of its competitors. In a large body of research, the size of a nation's economy has been shown to be an important determinant of the size of its international trade flows, with larger countries both importing and exporting more. Therefore, the brisk rate of, say, China's GDP growth relative to that of the United States would imply a higher Chinese share and a lower U.S. share in any product traded by both countries.

To assess the effect of GDP dynamics on the U.S. export share- and to distinguish this effect from changes in productivity-we conduct an empirical exercise in which we relate the

Box 1

\section{Relative Export Productivity and the Gains from Trade}

Determining if the relative productivity of U.S. firms is falling has important implications for assessing the benefits that the United States derives from engaging in international trade. Changes in the welfare gains from trade can be represented as changes in the ratio of a country's export prices to its import prices, with greater welfare arising when a country's exporting firms receive higher prices or when its consumers or importing firms pay lower prices. According to this taxonomy, classical trade theory would view deepening trade integration with emerging market economies and the associated decline in import prices as a boon to the aggregate gains from trade in spite of the negative effect on U.S. global export share. However, the effect of rising foreign productivity in U.S. export industries would decrease the price that U.S. firms receive for their export sales and hence decrease the size of U.S. gains from trade and the overall level of U.S. welfare.
Chart 1

\section{U.S. Share of World Exports}

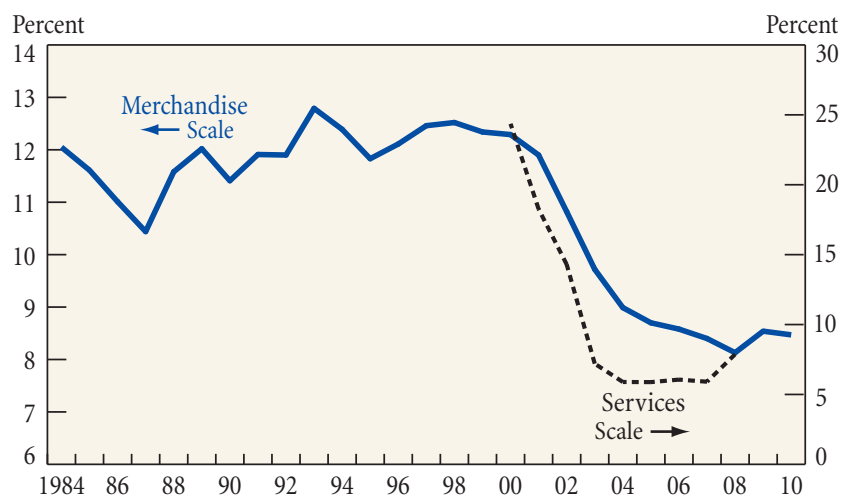

Sources: Aggregate U.S. and world merchandise trade data: Haver Analytics. Services data: United Nations Service Trade Statistics Database, available at http://unstats.un.org/unsd/servicetrade/.

Notes: Market shares are computed using current U.S. dollars. The services data include the following categories: transportation, travel, communications, construction, insurance, financial services, computer and information services, royalties and license fees, other business services, recreational services, and government services.

nation's export market share to its GDP share, geographic factors (such as the distance between import and export markets), and relative productivity. GDP share and geographic factors are easier to measure than productivity, and therefore our approach will be to subtract out their effect on market share. When we purge trade flows between pairs of countries of the effects of GDP growth and geography, what is left over-the residual—contains information about the exporter's productivity. One such residual measure is estimated below which, insofar as it is inferred from actual trade flows, is referred to as revealed competitiveness. Our calculations show that the United States' diminished share of global output accounts for about half of the decline in the U.S. export share. Flagging relative productivity may have played a role in export contraction in the early 2000s, but does not emerge as a large factor in the decline of the U.S. share of merchandise exports over the longer term.

\section{The Decline of the U.S. Export Share}

From 1984 to 2010, the U.S. share of global exports of goods fell by almost one-third. ${ }^{2}$ Through 1999 , it was fairly stable at a level of roughly 12 percent, then dropped 3.5 percentage points between 2000 and 2010 (Chart 1). For a subset of countries that report data on the export of certain services, we are able to construct an analogous measure of the U.S. services market share for the 2000-08 period (also shown in Chart 1). Clearly, the decline in U.S. share in the 2000s was not particular to merchandise exports: the services measure fell precipitously

\footnotetext{
${ }^{2}$ We use the terms goods and merchandise interchangeably in our analysis. We reserve the terms sector and product for narrower categories of traded goods.
} 
Chart 2

Sector Contributions to the Aggregate U.S. Share Decline
$1984-2008$

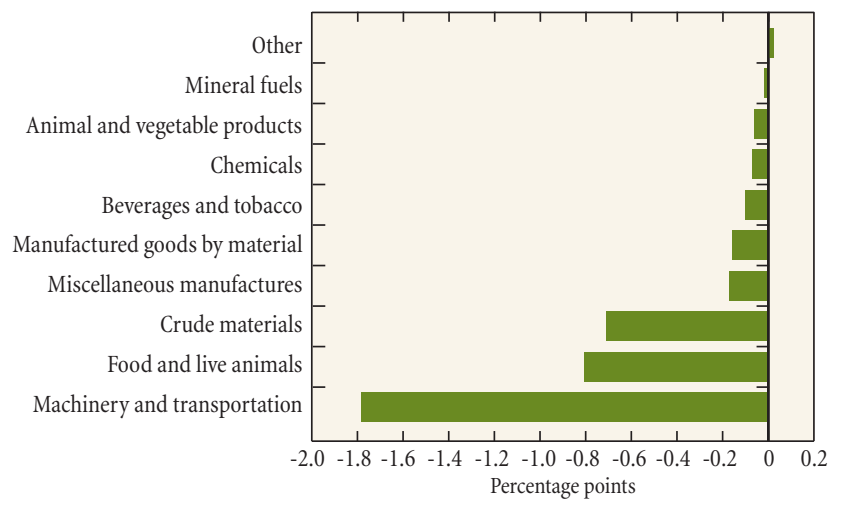

Sources: UN-NBER bilateral merchandise trade data; author's calculations.

from its initial value of about 25 percent before stabilizing in the later years at just above 5 percent. While the data's incomplete coverage of countries and services makes it difficult to ascribe too much precision to the services share levels, the dynamics of the services market share are remarkably similar to those of the goods market share. This finding rules out the argument that a U.S. industry shift from manufactured goods exports to services exports explains the drop in the U.S. share of merchandise exports.

In light of the limited data available on the services trade, we focus exclusively on merchandise trade in our effort to identify the forces underlying the nation's declining export market share. As a first step, we calculate the contributions that different product groups have made to the 3.5 percentage point fall in the goods export share (Chart 2). For this exercise, we use detailed international data — available through 2008 — that break down world trade into several hundred disaggregated products (Box 2). ${ }^{3}$ Grouping the products in the U.S. export data into broad sectors, we observe that virtually every sector registered a decrease in market share over the period from 1984 through 2008. The sector that contributed the most to the overall decline in share was machinery and transportation equipment, which alone accounted for half of the decrease in the U.S. export share over that period. This large contribution in part reflects the fact that machinery and transportation-related products represent almost half of U.S. exports. Within that sector, the declines in the U.S. share of office machine and computer exports are particularly striking, dropping from about a third of total world sales to just under one-tenth.

The vast majority of the remaining share losses were recorded in commodities categories, which account for approximately a quarter of U.S. export sales over the twenty-five years examined.

\footnotetext{
${ }^{3}$ Bilateral industry-level trade flows for merchandise are based on National Bureau of Economic Research-United Nations [NBER-UN] Trade Data compiled by Feenstra et al. (2005) and extended through 2008 using COMTRADE data.
}

\section{Box 2}

\section{Decomposing Changes in Market Share}

A useful way of accounting for the overall change in the U.S. share of world merchandise exports is to distinguish the contributions made by individual product sectors. This approach entails computing the appropriately weighted market share of each sector. Our first decomposition breaks down the changes in U.S. export sales into ten sectors, denoted by an $i$, and divides the sales in each sector by the change in the total value of world exports:

$$
\frac{\Delta X_{U S}}{\Delta X_{\text {WORLD }}}=\sum_{i=1}^{10} \frac{\Delta X_{U S}^{i}}{\Delta X_{W O R L D}} .
$$

Since the contributions of all $i$ 's add up exactly to the 3.5 percentage point decline observed in the overall U.S. share, this measure provides a simple way of examining how evenly distributed the overall change is across broad economic units. Also note that this same decomposition can be applied easily to more narrowly defined products, with the only difference being the larger number of $i$ 's and the lower level of each product's contribution.

Next, we distinguish changes in the U.S. market share that are related to the nation's competitiveness from those that reflect only the changing composition of the global set of traded goods. One established method of assessing the importance of composition for changes in trade shares is constant market share analysis. It involves separating the changes in aggregate market share into two components: a commodity effect and a competitiveness effect. These effects correspond to the intensive and extensive effects described in the text, and are defined as follows:

$$
\frac{\Delta X_{U S}^{i}}{\Delta X_{\text {WORLD }}} \approx \underbrace{\sum_{i=1}^{\sum_{\text {WORLD }} \frac{X_{U S}^{i}}{X_{\text {US }}^{i}}} \cdot\left(\Delta \frac{X_{\text {WORLD }}^{i}}{X_{\text {WORLD }}}\right)}_{\text {Commodity (Extensive) }}+\underbrace{\sum_{i=1}^{10}\left(\Delta \frac{X_{\text {US }}^{i}}{X_{\text {WORLD }}^{i}}\right) \cdot \frac{X_{\text {WORLD }}^{i}}{X_{\text {WORLD }}}}_{\text {Competitiveness (Intensive) }} .
$$

The commodity (extensive) effect measures the role of composition in a change in the aggregate export share. By weighting the change in the size of a sector in world trade by the average share of U.S. exports in that sector, we approximate what would have happened to the overall share if the U.S. piece of the pie (that is, share in each sector) had stayed constant and only the size of the pie (that is, the size of each sector) had changed. The competitiveness (intensive) effect measures the portion of the aggregate share change that is attributable to the U.S. share of exports within each sector; that is, it approximates the effect of holding the size of the pie constant and changing only the size of the U.S. slice. In other studies, the constant market share approach often includes an additional "market effect" related to the idiosyncratic characteristics of each export destination market. For ease of exposition, we have focused only on the commodity effect, in a sense wrapping the market effect into our measurement of the competitiveness effect.

For a more detailed description of constant market share analysis and for an example of how it has been recently applied to measuring competitiveness, see di Mauro et al. (2005). Note, however, that this technique is beset by a number of well-documented theoretical problems, and the interested reader is referred to Richardson (1971) for an overview of those. In spite of these problems, the approach remains informative for our purposes. 
For instance, the contributions of crude materials (a category that includes, among other things, metals and minerals with low levels of processing) and food and live animals added up to about 1.5 percentage points, accounting for 43 percent of the overall change in the U.S. share. ${ }^{4}$

The importance of commodities for the decline in the U.S. share offers our first reason to resist interpreting aggregate export share statistics as direct evidence of declining competitiveness. Commodity prices fell over most of the period under consideration and, since the exports of the United States are relatively commodity-intensive, it follows that U.S. revenue from commodity sales - and hence the U.S. share of world exportswould fall as well. This point is reinforced by price trends for those individual products within the commodities categories that contributed the most to the share decline. For instance, the prices of corn and soybeans fell in the late 1990s and then remained at this lower level until 2006, when they began to rise. This pattern of prices corresponds closely to the rapid decline in the U.S. export share at the beginning of the past decade and its leveling off in the middle of the decade. Thus, it appears likely that movements in the U.S. export share partly reflect commodity price fluctuations - as opposed to being driven entirely by changes in U.S. competitiveness.

Commodity price effects aside, the importance of foods for explaining the overall decline in the U.S. export share is still somewhat surprising given food's relatively small share in U.S. exports. Note, however, that the contribution of each sector occurs along both an "intensive" and an "extensive" margin. Expressed differently, the decline in the U.S. aggregate share reflects both a decline in market share within each sector (the intensive margin), as well as a decline stemming from changes in the size of each category relative to world exports (the extensive margin). For instance, corn contributes to the decline in U.S. aggregate share both when the United States captures a smaller proportion of the corn-specific export market and when corn's share of overall world exports declines. Intensive margin changes are more closely related to competitiveness, since they gauge the size of the "slice of the pie" held by U.S. exporters, whereas extensive margin changes relate to the size of a given product or sector-that is, they measure the size of the pie itself without regard to how it is split among competing exporters. If we adhere to a definition of competitiveness that focuses on the intensive margin, it does not matter whether a country gains market share in slow- or fast-growing sectors, but only that it increases its market share. Arguably, a country would prefer to specialize more deeply (and gain market share) in faster-growing sectors. That said, over our relatively short period of analysis, it is probably reasonable to assume that the sector composition of exports by any given country does not change that much.

\footnotetext{
${ }^{4}$ Another third of a percentage point is accounted for by miscellaneous manufactured products, which primarily includes footwear, clothing, apparel, furniture, and certain scientific or photographic apparatus, and manufactured goods classified by material, which includes material-intensive products such as textiles, metal and mineral manufactures, pulp, paper, and rubber.
}

Chart 3 Intensive and Extensive Margin Contributions
to the Aggregate U.S. Share Decline
1984-2008

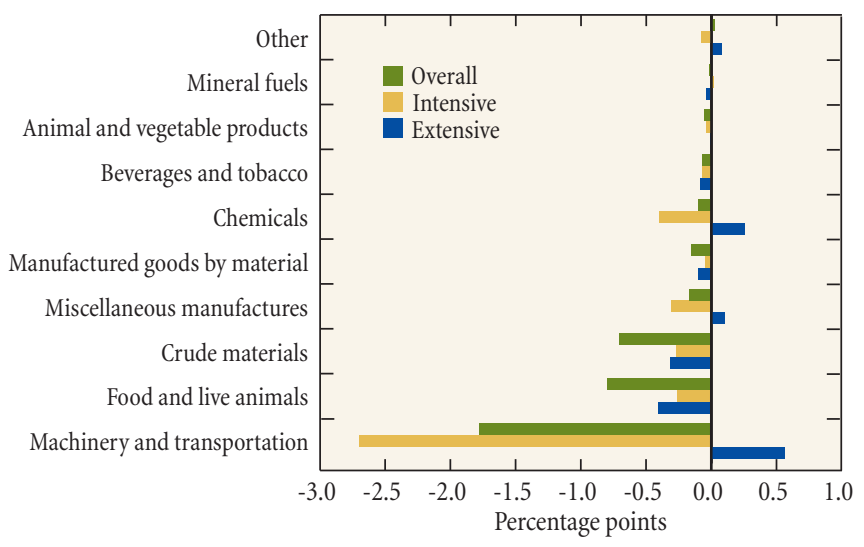

Sources: UN-NBER bilateral merchandise trade data; author's calculations.

In the second step of our analysis of the changing U.S. export share, we decompose the overall contributions of each sector into intensive and extensive effects over the 1984-2008 period (Chart 3).(For more detail on the calculations, see Box 2.) Our conjecture that commodity prices and other factors unrelated to competitiveness are at play is supported by the fact that both the food and live animals sector and the crude materials sector have large negative extensive margin effects. Thus, the large negative contributions of the two sectors for the most part reflect the declining importance of these goods in world merchandise exports, although U.S. exports also suffered a negative intensive effect in each case. In contrast, the negative overall contributions of machinery and transportation, miscellaneous manufactured products, and chemicals can be completely attributed to a decline in U.S. competitiveness, because these sectors increased their weight in world exports over the time frame under consideration.

In sum, we have seen that compositional effects make it difficult to attribute all of the observed decline in U.S. export share to the nation's faltering competitiveness. The commodities sector was one of the primary drivers of the decline, yet its contribution to export share losses largely derived from the declining weight of commodities in the world export basket as well as the price fluctuations of these goods. That said, the United States did experience large declines in share in machinery, transportation products, miscellaneous manufactures, and chemicals that no doubt reflected ground lost to competitors within those sectors. In the case of these export sectors, the evidence of a fall in U.S. competitiveness is more compelling.

The next section focuses on U.S. export performance within more narrowly defined industries and attempts to identify the drivers of the intensive margin effect more precisely. An empirical methodology is suggested that produces a more finely tuned measure of competitiveness: exporter market share after 

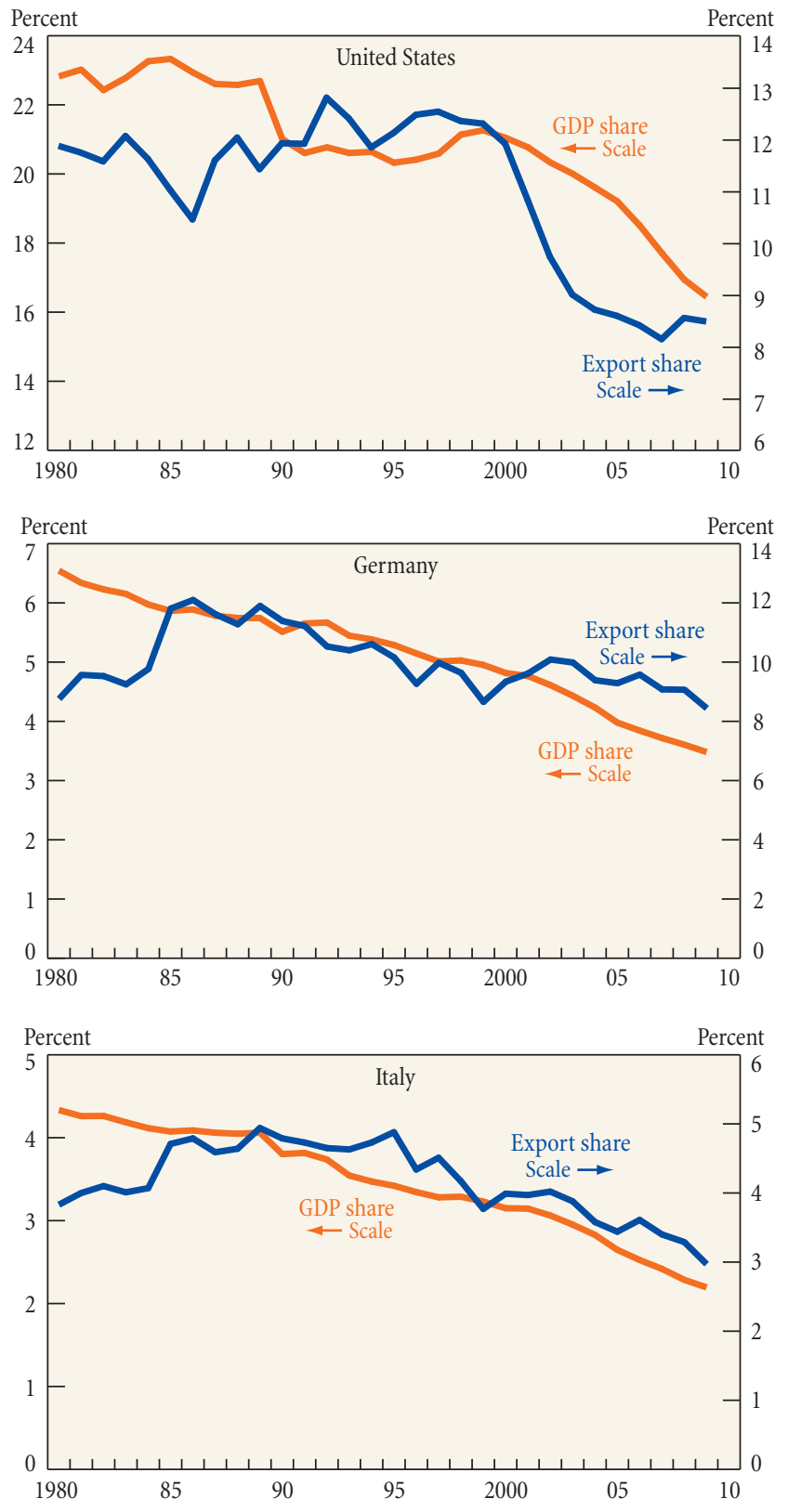

controlling for changes in the relative market size of trading partners. This measure is termed revealed competitiveness.

\section{Calculating Revealed Competitiveness}

One possible explanation for the intensive margin decline in the U.S. export share is simply that the nation now accounts for a smaller share of global output. As emerging market economies expand rapidly and become more integrated with the global economy, it is natural that the U.S. share of world exports would fall; the decline does not necessarily imply any drop-off in the relative productivity of U.S. exporters. By extension, the fast-
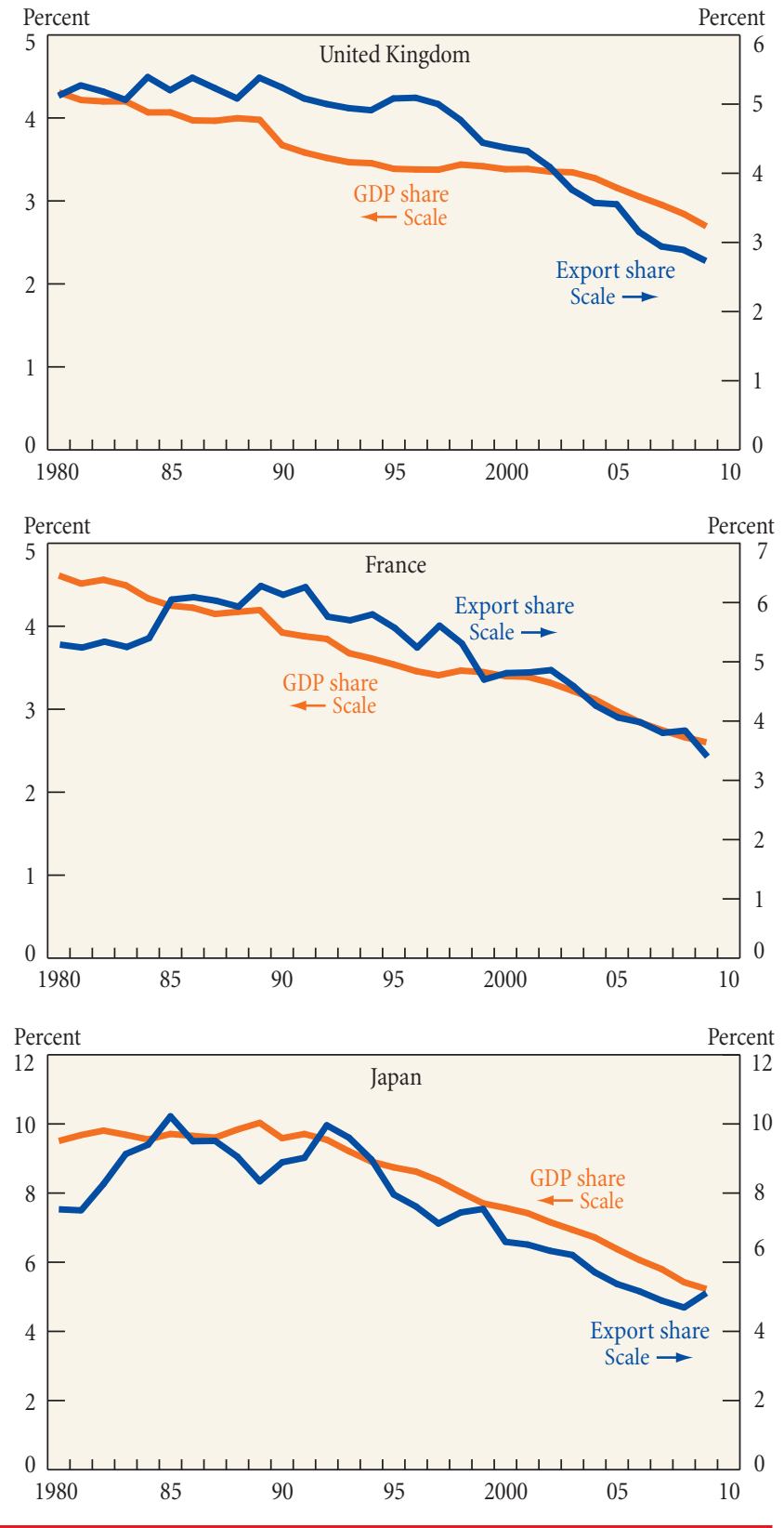

growing domestic market for goods in these countries may provide a boon to their exporters simply because of the larger scale of production.

Evidence of a relationship between a country's export performance and its output appears in Chart 4, which plots the share of global exports alongside the share of global GDP for several countries. In the case of the United States, the GDP share, like the export share, was fairly steady leading up to the year 2000. Subsequently, the fall in the U.S. share of global exports of about 3.5 percentage points through 2008 corresponded to a decrease in the U.S. share of global GDP of about 4.5 percentage points. 
Chart 4 (Continued)

\section{Export and GDP Shares}
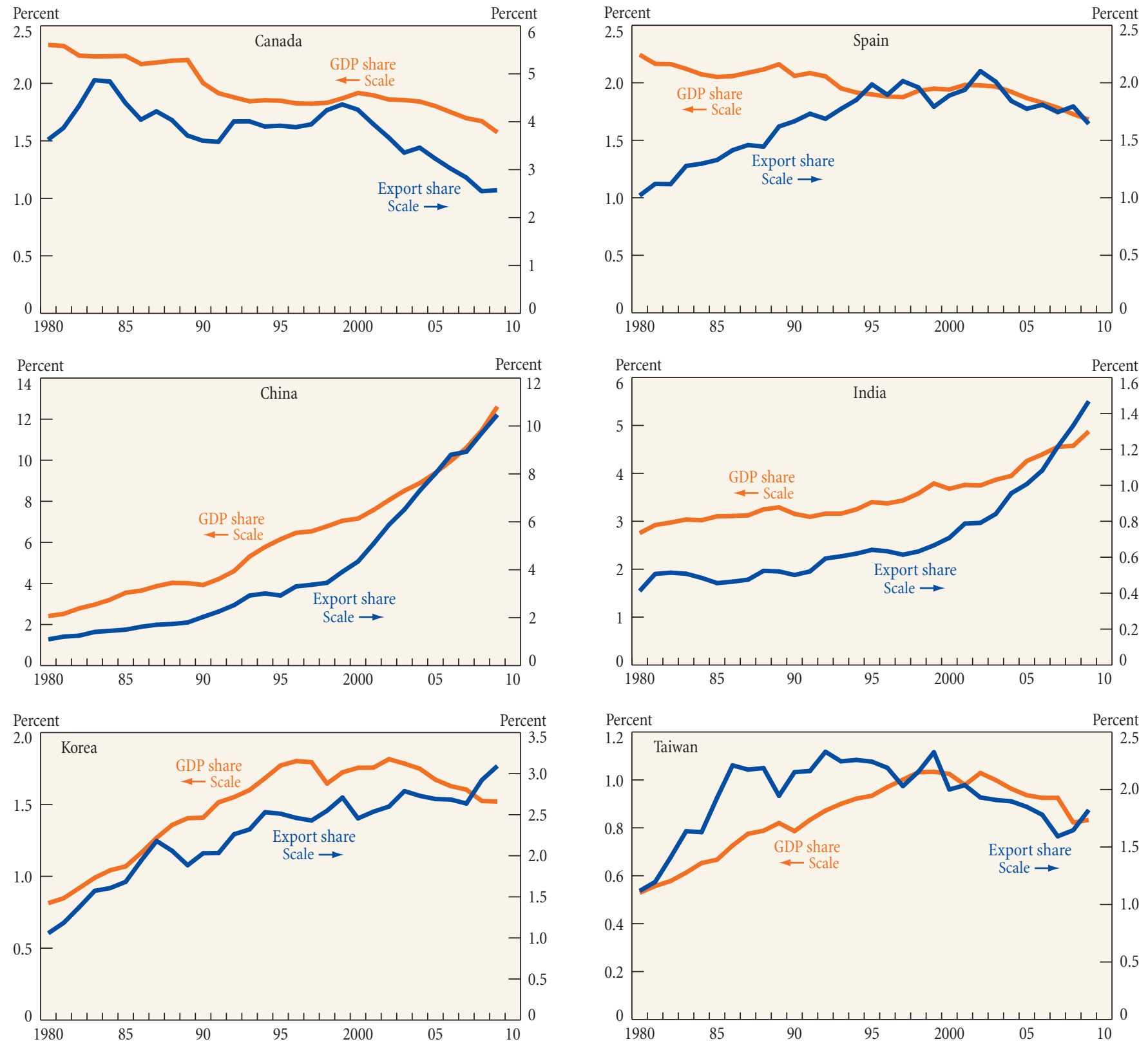

Sources: Haver Analytics; author's calculations.

The relatively tight correlation between export share and GDP share holds true for many other countries as well. Among the Group of Seven countries, France, the United Kingdom, Italy, Canada, and Japan have experienced declines in export share that broadly match their declining share of world output. The biggest exception to this pattern is Germany, which has more or less maintained export share even as its share of world output has declined. Turning to the export-intensive Asian economies, we note that, in percentage terms, the export share growth of both China and India has moved upward in tandem with their GDP shares.

The implication of the Chart 4 patterns is that changes in market share may be conflating competitiveness effects with country characteristics such as output dynamics. To control for such characteristics and isolate the contribution of relative productivity to changes in country export shares, we construct 
a measure of export share growth that subtracts out the contribution of country size. To this end, we use a model of international trade flows called the gravity model.

Like its namesake in the physical sciences, the gravity model specifies that the size of trade flows is proportional to the size (or mass) of the two trading partners and factors such as tariffs, transportation costs, and other trade costs (or distance). The model has a strong empirical track record and has been the subject of a battery of empirical tests and applications. Several previous studies have used it to decompose the levels of bilateral trade flows into contributions from GDP, trade costs, and other factors. ${ }^{5}$ Consistent with the graphic evidence presented in our Chart 4, these studies find that exporter and importer outputs play substantial, even dominant, roles in explaining trade. Our approach extends this logic to the case of relative trade performance, where the gravity equation is "folded" into an equation relating an exporter's market share to its GDP share, its relative productivity, and relative geographic factors such as the distance between the export and import markets. ${ }^{6}$ The average relationship between export share, GDP share, and geography is then estimated for each product in the bilateral trade data set; the residual — that is, what is left over after GDP and geographic factors are accounted for-is a measure of the export share that contains more precise information about changes in an exporter's relative productivity.

Is this residual an exact measure of relative productivity? Probably not. Our empirical exercise does not control for policy changes such as a foreign country's decision to decrease its tariffs, a move that would increase the volume of exports flowing to that country from other nations. We do control for large-scale shifts in policy such as the introduction of the North American Free Trade Agreement and the establishment of the European Economic and Monetary Union. Nonetheless, the residual likely captures elements of falling trade costs in addition to relative productivity. A phenomenon closely related to falling trade costs is the recent growth in the incidence of international outsourcing, in which certain stages or tasks in a production process take place in a foreign country. Increased outsourcing would also show up in our measure of revealed competitiveness, since more goods are being traded for the production of the same amount of final outputs. Consequently, with this exercise we are jointly estimating relative performance attributable to productivity and these additional factors, all of which fit into a reasonable, if broad, definition of export competitiveness.

\section{Data and Results}

For our estimation, we use the bilateral trade flow data described in this article's first section as well as nominal GDP data from

\footnotetext{
${ }^{5}$ See, for example, Baier and Bergstrand (2001) and, more recently, Whalley and Xin (forthcoming) and Novy (forthcoming).

6 "Folding" entails dividing the bilateral trade flows in the gravity equation by those of a particular exporting country, a step that has the benefit of simplifying the equation by canceling out several importer-specific terms.
}

the Penn World Table. ${ }^{7}$ We then run a gravity regression for each of the several hundred products in the data set. With our estimates of the average relationships between exports, GDP, and geographic factors for each product, we decompose the U.S. export share into a portion explained by these factors (that is, a model prediction) and a portion not explained by these factors (that is, a residual). We interpret the residual as a measure related to changing productivity and trade costs.

The main results of our estimation are summarized in Chart 5. Adding up all of the products, the chart illustrates the relative quantitative importance of the model prediction and the residual components of the overall U.S. export share. The chart presents two measures of the overall share, one based on aggregate statistics (as in Chart 1) and the other on the detailed product-level trade data used for the gravity regressions. Note that the two measures, though drawn from different data sources, correspond very closely.

Overall, the model prediction tracks much of the decline in the U.S. market share. In 2008, at the end of the sample period, the model prediction is about 15 percent below its level in the year 2000, accounting for about half of the 30 to 35 percent drop in the U.S. share. The residual, our measure of revealed competitiveness, accounts for the other half. The ability of the model to track the decline in the U.S. market share is closely related to the positive correlation between the country's GDP share and export share observed in Chart 4. However, we have now quantified how meaningful a relationship this is in units of market share and significantly narrowed the portion of market share change that could be attributed to changing relative productivity.

While the model is effective overall in accounting for half of the cumulative market share change over the sample period, it performs better in some periods than in others. This finding, in turn, has implications for our interpretation of the dynamics of U.S. relative productivity. In particular, the model tracks the flat periods in the market share series (that is, 1994-2000, 2005-08), but misses the decline in U.S. share in the early 2000s. By contrast, the residual declined sharply in the beginning of the 2000s - an indication that relative productivity fell at that time, before stabilizing in the middle of the decade. Overall, Chart 5 shows that U.S. relative productivity, albeit in decline by this measure of revealed competitiveness, did not decline by nearly as much as the fall of the U.S. export share might suggest.

Moreover, this result obtains broadly across product categories. Even in the categories of machinery and transportation, where U.S. share performance was particularly weak and exclusively driven by changes in the intensive margin, a significant share of

\footnotetext{
${ }^{7}$ The Penn World Table, available at http://pwt.econ.upenn.edu/, is published by the Center for International Comparisons at the University of Pennsylvania. We follow previous studies by excluding very small trade flows; this precaution avoids potential distortions from errors of units in the data and from implausibly small trade values. The remaining data account for more than 80 percent of global trade value between 1980 and 2008 .
} 


\section{Chart 5 \\ Predicted and Actual Measures of the U.S. Share of World Merchandise Exports}

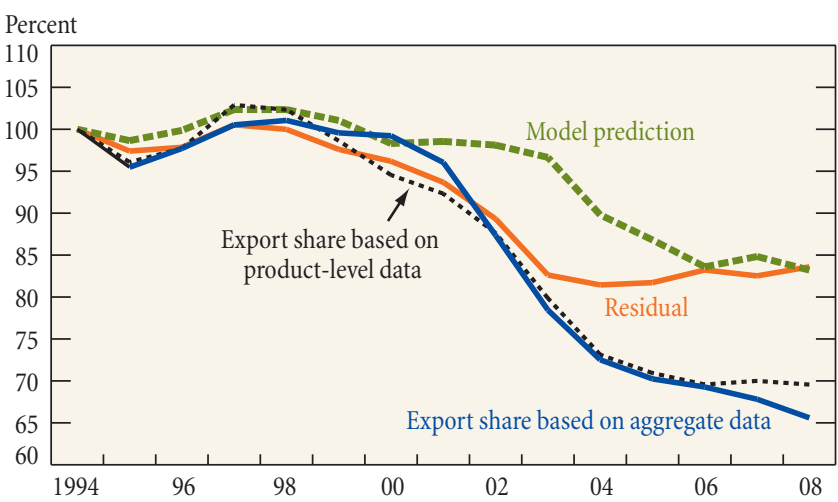

Sources: Aggregate data: Haver Analytics. Product-level data, model prediction, and residual: UN-NBER bilateral merchandise trade data; author's calculations.

Note: All data are indexed to the base year 1994.

the decline can be accounted for by GDP and geographic factors. Further, the percentage change in the residual for machinery and transportation was roughly equal to that for crude materials and food and live animals, categories that had much smaller intensive margin share declines.

As for the other exporters in our data set, clear winners and losers emerge. Indonesia, China, India, and Mexico had among the highest increases in their residual - that is, the greatest gains in their competitiveness - by a large margin, as their export growth far outpaced the increase in their GDP shares. By contrast, certain large Asian exporters had dramatic falls in their residuals, presumably owing to the rise of China and large increases in Mexican exports to the United States over the sample period. European countries and Canada had more moderate changes in their export performance and, with a few exceptions, tended to lag behind the rest of the world.

One factor that likely contributed to the more extreme gains and losses experienced by some countries is cross-border production sharing. Countries that make intensive use of foreign inputs in their production processes would record higher exports for a given unit of output independent of exporter productivity. This factor may be behind some of the high measures of performance that we estimate for China and Mexico. Analogously, the losses in competitiveness that we find for East Asian countries excluding China may owe something to the large flows of goods passing through China for final assembly. Though beyond the scope of this article, an interesting extension of our line of research would be to estimate countries' revealed competitiveness while controlling for the extent of international production in their industries.
Conclusion

The downward drift in the U.S. share of world merchandise trade stems from a number of sources, and does not appear to signal a dire loss of relative productivity for U.S. exporters as a group. A substantial portion of the nation's declining export share over the past fifteen years is explained by compositional factors - the shifting make-up of global exports and the smaller share of overall exports claimed by some key U.S. products - and by the changing size of the U.S. economy relative to that of its competitors. These findings argue against treating the export share of a country as a wholly reliable measure of its competitiveness.

In this article, we have presented an alternative measure of exporter competitiveness that controls for changes in the overall composition of exports and GDP dynamics. Even our revealed competitiveness measure, however, may not be an entirely accurate gauge of relative productivity. As we have seen, the measure may be capturing a number of factors unrelated to productivity, including commodity prices, evolving trade costs, and the international outsourcing of production processes. These ambiguities make it even more difficult to conclude that we are witnessing a broad-based decline in the ability of U.S. firms to compete in global markets.

The empirical methodology and results in this article draw on joint work with Massimo Del Gatto of G. d'Annunzio University, Filippo di Mauro of the European Central Bank, and Joseph Gruber of the Board of Governors of the Federal Reserve System. For a more detailed exposition of the methodology and results, interested readers are referred to International Finance Discussion Paper no. 1026, available at http://www.federalreserve.gov/pubs/ifdp/.

\section{References}

Baier, Scott L., and Jeffrey H. Bergstrand. 2001. "The Growth of World Trade: Tariffs, Transport Costs, and Income Similarity." Journal of International Economics 53, no. 1 (February): 1-27.

Del Gatto, Massimo, Filippo di Mauro, Joseph Gruber, and Benjamin R. Mandel. 2011. "The Revealed Competitiveness of U.S. Exports." Board of Governors of the Federal Reserve System, International Finance Discussion Paper no. 1026, August.

di Mauro, Filippo, et al. 2005. “Competitiveness and the Export Performance of the Euro Area." European Central Bank Occasional Paper Series, no. 30, June.

Feenstra, Robert C., Robert E. Lipsey, Haiyan Deng, Alyson C. Ma, and Henry Mo. 2005. "World Trade Flows: 1962-2000." NBER Working Paper no. 11040, January.

Novy, Dennis. Forthcoming. "Gravity Redux: Measuring International Trade Costs with Panel Data." Economic Inquiry.

Richardson, J. David. 1971. "Constant-Market-Shares Analysis of Export Growth.” Journal of International Economics 1, no. 2 (May): 227-39.

Whalley, John, and Xian Xin. Forthcoming. "Regionalization, Changes in Home Bias, and the Growth of World Trade." Journal of Policy Modeling. 


\section{ABOUT THE AUTHOR}

Benjamin R. Mandel is an economist in the International Research Function of the Federal Reserve Bank of New York.

Current Issues in Economics and Finance is published by the Research and Statistics Group of the Federal Reserve Bank of New York. Linda Goldberg, Erica L. Groshen, and Thomas Klitgaard are the editors.

The content co-editor of this article is Mary Amiti.

Editorial Staff: Valerie LaPorte, Mike De Mott, Michelle Bailer, Karen Carter, Anna Snider

Production: Carol Perlmutter, David Rosenberg, Jane Urry

Subscriptions to Current Issues are free. Send an e-mail to Research.Publications@ny.frb.org or write to the Publications Function, Federal Reserve Bank of New York, 33 Liberty Street, New York, N.Y. 10045-0001. Back issues of Current Issues are available at http://www.newyorkfed.org/research/current_issues/.

The views expressed in this article are those of the author and do not necessarily reflect the position of the Federal Reserve Bank of New York or the Federal Reserve System.

Follow us on Twitter: @NYFedResearch

RELATED READINGS: INTERNATIONAL TRADE AND THE GLOBAL ECONOMY

\section{Liberty Street Economics Blog Posts}

Available at http://libertystreeteconomics.newyorkfed.org/

Central Bank Imbalances in the Euro Area

Matthew Higgins and Thomas Klitgaard

December 21,2011

Back to the Future: Revisiting the European Crisis

Paolo Pesenti

October 17, 2011

What If the U.S. Dollar's Global Role Changed?

Linda Goldberg, Mark Choi, and Hunter Clark

October 3,2011

An Examination of U.S. Dollar Declines

Roosevelt D. Bowman and Jan J. J. Groen

September 26, 2011

Consumer Goods from China Are Getting More Expensive

Mary Amiti and Mark Choi

September 7,2011
International Spillovers on Government Bond Yields:

Are We All in the Same Boat?

Vivian Z. Yue and Leslie Shen

August 1,2011

\section{The Vanishing U.S.-E.U. Employment Gap}

Christian Grisse, Thomas Klitgaard, and Ayşegül Şahin

July 25, 2011

Would a Stronger Renminbi Narrow the U.S.-China Trade Imbalance?

Matthew Higgins and Thomas Klitgaard

July 13, 2011

Did Trade Finance Contribute to the Global Trade Collapse? Mary Amiti and David Weinstein June 29, 2011 


\section{Articles and Papers}

Available at http://www.newyorkfed.org/research/publication_annuals/index.html

House Price Booms, Current Account Deficits,
and Low Interest Rates

Andrea Ferrero

Staff Reports, no. 541, January 2012

One of the most striking features of the period before the Great Recession is the strong positive correlation between house price appreciation and current account deficits, not only in the United States but also in other countries that have subsequently experienced the highest degree of financial turmoil. A progressive relaxation of credit standards can rationalize this empirical observation. Lower collateral requirements facilitate access to external funding and drive up house prices. The current account turns negative because households borrow from the rest of the world. At the same time, however, the world real interest rate counterfactually increases. Nominal interest rates departing from a standard monetary policy rule in leveraged economies, as well as foreign exchange rate pegs in saving countries, help reconcile a demand-based explanation of house price booms and current account deficits with the evidence on real interest rates.

\section{The Hitchhiker's Guide to Missing Import Price Changes and Pass-Through}

Etienne Gagnon, Benjamin R. Mandel, and Robert J.Vigfusson Staff Reports, no. 537, January 2012

A large body of empirical work has found that exchange rate movements have only modest effects on inflation. However, the response of an import price index to exchange rate movements may be underestimated because some import price changes are missed when constructing the index. The authors investigate downward biases that arise when items experiencing a price change are especially likely to exit or to enter the index. They show that, in theoretical pricing models, entry and exit have different implications for the timing and size of these biases. Using Bureau of Labor Statistics microdata, they derive empirical bounds on the magnitude of these biases and construct alternative price indexes that are less subject to selection effects. The analysis suggests that the biases induced by selective exits and entries do not materially alter the literature's view that passthrough to U.S. import prices is low over the short- to mediumterm horizons that are most useful for both forecasting and differentiating among economic models.
Monetary Policy Implementation: Common Goals but Different Practices

Marlene Amstad and Antoine Martin Current Issues in Economics and Finance, vol. 17, no. 7, 2011

While the goals that guide monetary policy in different countries are very similar, central banks diverge in their methods of implementing policy. This study of the policy frameworks of four central banks - the Federal Reserve, the European Central Bank, the Bank of England, and the Swiss National Bank-focuses on two notable areas of difference. The first is the choice of an interest rate target, a standard feature of conventional monetary policy. The second is the choice of instruments for managing the central banks' expanded balance sheets—a decision made necessary by the banks' unconventional practice of acquiring large quantities of assets during the financial crisis.

\section{Saving Imbalances and the Euro Area Sovereign Debt Crisis}

Matthew Higgins and Thomas Klitgaard Current Issues in Economics and Finance, vol. 17, no. 5, 2011

For several years prior to 2010, countries in the euro area periphery engaged in heavy borrowing from foreign private investors, allowing domestic spending to outpace incomes. Now these countries face debt crises reflecting a loss of investor confidence in the sustainability of their finances. The result has been an abrupt halt in private foreign lending to these economies. This study explains how the periphery countries became dependent on foreign borrowing and considers the challenges they face reigniting growth while adjusting to greatly reduced access to foreign capital.

Liquidity Management of U.S. Global Banks: Internal Capital Markets in the Great Recession

Nicola Cetorelli and Linda Goldberg

Staff Reports, no. 511, August 2011

The recent crisis highlighted the importance of globally active banks in linking markets. One channel for this linkage is the liquidity management of these banks, specifically the regular flow of funds between parent banks and their affiliates in diverse 
foreign markets. The authors use the Great Recession as an opportunity to identify the balance sheet shocks to parent banks in the United States and then explore which features of foreign affiliates are associated with protecting, for example, their status as important locations in sourcing funding or as destinations for foreign investment activity. They show that distance from the parent organization plays a significant role in this allocation, where distance is bank affiliate-specific and depends on the location's ex ante relative importance in local funding pools and overall foreign investment strategies. These flows are a form of global interdependence previously unexplored in the literature on international shock transmission.

\section{The Dynamics and Differentiation of Latin American Metal Exports}

Benjamin Mandel

Staff Reports, no. 508, August 2011

This paper investigates the propensity of exporters in certain primary commodity sectors to innovate and then attempts to measure the associated gains. The high degree of differentiation in metal products is giving rise to the potential for vertical upgrading for a substantial portion of Latin American export sales. Estimation of a demand system for U.S. imports shows that relatively high-priced new varieties tend to gain market share, which suggests a correspondingly large increase in the relative quality of those varieties. Breaking down the types of metal products by order of their value-added in production reveals a pattern of specialization away from low-value ores and toward high-value intermediate and finished products. Upgrading varieties and shifting specialization to downstream outputs account for the vast majority of Latin America's increasing market share in metals over the past thirty years.

\section{Financial Amplification of Foreign Exchange Risk Premia}

Tobias Adrian, Erkko Etula, and Jan J. J. Groen

Staff Reports, no. 461, July 2010; revised November 2010

Theories of financial frictions in international capital markets suggest that financial intermediaries' balance sheet constraints amplify fundamental shocks. This study presents empirical evidence for such theories by decomposing the U.S. dollar risk premium into components associated with macroeconomic fundamentals and a component associated with financial intermediary balance sheets. Relative to the benchmark model with only macroeconomic state variables, balance sheets amplify the U.S. dollar risk premium. The authors discuss applications to financial stability monitoring.

\section{The Federal Reserve's Foreign Exchange Swap Lines \\ Michael J. Fleming and Nicholas J. Klagge \\ Current Issues in Economics and Finance, vol. 16, no. 4, 2010}

The financial crisis that began in August 2007 disrupted U.S. dollar funding markets not only in the United States but also overseas. To address funding pressures internationally, the Federal Reserve introduced a system of reciprocal currency arrangements, or "swap lines," with other central banks. The swap line program, which ended early this year, enhanced the ability of these central banks to provide U.S. dollar funding to financial institutions in their jurisdictions.

\section{Outsourcing and Pass-Through}

Rebecca Hellerstein and Sofia Berto Villas-Boas Staff Reports, no. 251, April 2006; revised June 2010

A large share of international trade occurs through intrafirm transactions. The authors show that this common crossborder organization of the firm has implications for the welldocumented incomplete transmission of shocks across such borders. Their analysis presents new evidence of an inverse relationship between a firm's outsourcing of inputs and its rate of exchange rate pass-through. The authors then develop a structural econometric model with final assemblers and upstream parts suppliers to quantify how firms' organization of their activities across national borders affects their passthrough behavior.

\section{Are We Understanding the Gains from Globalization for the United States? \\ David Weinstein and Christian Broda Current Issues in Economics and Finance, vol. 11, no. 4, 2005}

Over the last three decades, trade has more than tripled the variety of international goods available to U.S. consumers. Although an increased choice of goods clearly enhances consumer well-being, standard national measures of welfare and prices do not assign a value to variety growth. This analysis - the first effort to measure such gains - finds that the value to consumers of global variety growth in the 1972-2001 period was roughly $\$ 260$ billion. 